\title{
Feeling Poor, Acting Stingy: The Effect of Money Perceptions on Charitable Giving
}

Pamala Wiepking, VU University Amsterdam, the Netherlands (P.Wiepking@fsw.vu.nl)

Beth Breeze, University of Kent, United Kingdom (B.Breeze@kent.ac.uk)

Draft, please do not quote without permission from the authors

Paper prepared for presentation at the ARNOVA Conference, Philadelphia, Nov 20-22, 2008

November 26,, 2008

\section{Abstract}

In philanthropic research, much attention has been given to the impact of the actual costs of giving. In this paper we argue that, in addition to actual costs, the perceived costs of giving should be taken into consideration when seeking to understand the incidence and scale of charitable giving. We know from the economic and sociological literature that people differ in their attitudes towards money (Furnham and Argyle 1998; Zelizer 1989) but these findings have largely been overlooked within philanthropic studies. Whilst 'money perceptions' have been mentioned in passing in a number of academic studies (for example Wright 2002), and in some non-academic fundraising literature (notably Rosenberg 1994), attitudes towards money are rarely considered as a key explanatory factor behind the propensity to give and decisions regarding size of gifts. This paper seeks to rectify that situation by focusing on hypotheses that explore the effects of money perceptions on charitable giving. The hypotheses are developed from qualitative data found in existing UK datasets in which the wealthy account for their decision to give or withhold donations. We find that, regardless of the actual financial resources held by the individual, the decision to give and the size of gift are negatively affected by feelings of retention (a careful approach to money) and inadequacy (people who worry about their financial situation). Feeling financial secure positively affects the act of making donations. We conclude that money perceptions are an additional significant variable in explaining incidence and level of charitable donations.

\section{Introduction}

Sir Tom Hunter, Scotland's first home-grown billionaire and the most prominent contemporary UK philanthropist, recently explained how he tries to enthuse his fellow superrich to follow his philanthropic lead. He tells them, "I'm having the time of my life and I want to 
tell others on the Rich List to do this, once they've met all their material goals"1. To appear on the UK Rich List, which is published annually by the Sunday Times newspaper, an individual must be worth a minimum of $£ 80$ million. The idea that someone worth $£ 80$ million or more can still have material needs to be fulfilled before they can turn their attention to philanthropic acts, is an appropriate starting point for this paper, which explores attitudes towards money and argues that an understanding of 'money perceptions' can help to explain both the incidence and level of charitable giving.

The observation that perceptions about wealth have an impact on actual giving behaviours is obviously not confined to the UK. A month before Hunter's comments a young American inheritee, Tyrone Boucher, announced he wanted to donate his six-figure trust fund to charity because he was concerned about the growing gap between the rich and the poor, to which his father responded, 'Tyrone, we're not really rich. There are people who have multiple homes and private jets.' 'Boucher replied, 'But the thing is, you're talking about your friends who are in the top 1 percent, and we're in the top 5 percent'. Reflecting on this exchange, Boucher claims, "The point isn't to dis my dad. The point is, what's enough?"2

The question 'what's enough?' is of crucial importance in understanding decision making around charitable giving, because the answer defines the subjectively-assessed boundary between necessary and surplus income; the greater the surplus, the greater the capacity to give. This paper presents the first study that focuses on money perceptions as a key explanatory variable. It asks if the different attitudes that people hold towards money can account for differences in charitable giving, regardless of their actual financial resources.

The paper begins with a discussion of the literature, including an overview of the different attitudes people can have toward money. After that, we implement these different attitudes in order to formulate hypotheses on how money perceptions and attitudes affect incidence and level of charitable giving. We use qualitative data considering rich donors in the UK (Breeze 2006; Edwards 2002; Lloyd 2004) to illustrate how money perceptions and attitudes affect decisions to give or withhold donations. Finally, we use a quantitative dataset on Dutch donors to empirically test a) how money perceptions relate to actual financial resources; and b) how money perceptions and actual financial resources relate to incidence and level of charitable giving. With this study we hope to provide new answers to the question of why people give, and why some people give more, to charitable organizations.

\footnotetext{
${ }^{1}$ Hunter was speaking at a breakfast seminar organised by the Charities Aid Foundation on 29/4/08 to mark the launch of the Giving List, a sub-section within the Sunday Times Rich List that identifies the most philanthropic members of the Rich List.

${ }^{2}$ As reported in the International Herald Tribune, 13/3/08
} 


\section{Literature review}

In an overview study of philanthropic behaviours, Bekkers and Wiepking (2007) argue that the actual cost of donations is one of eight mechanisms that drives charitable giving, alongside awareness of need, solicitation, altruism, reputation, (psychological) benefits, values, and efficacy. It is clear that giving money costs money; the higher the actual costs of donations, the less people will be able and inclined to give. In many countries - including the UK, the Netherlands, and the US - giving to charitable causes is tax deductible. This makes the real costs of a donation smaller than the donation itself. Most tax systems stimulate charitable behaviour in such a way that people on higher incomes (and therefore with the capacity to make larger donations) are given more incentives than people on lower incomes and pay a relatively lower price of giving than people in lower tax categories. Thus, the higher a household's income, the lower the actual costs for making charitable donations. Economists call the actual costs of donations the 'price of giving' (Andreoni 2004; Vesterlund 2006). There is overwhelming evidence of an inverse correlation between the price of giving and the incidence and size of charitable donations (Peloza and Steel 2005; Simmons and Emanuele 2004; Steinberg 1990).

Whilst the impact of the actual price of giving has attracted the attention of many scholars, there is minimal understanding of how perceived costs affect charitable giving. By 'perceived costs' we mean the costs of donations as experienced by donors and potential donors, which might also be described as the psychological price of giving.

Foremost amongst those who have emphasised this factor was the late Claude Rosenberg, whose advocacy of tithing was based on a belief that most people systematically underestimated their wealth and, subsequently, their capacity to give (Rosenberg 1994). A handful of academic studies mention the effects of perceived costs of donations either in passing or very briefly. Wright's discussion of the different giving ethos and behaviours found in the US and the UK suggests that one explanation amongst many could involve different attitudes towards wealth, including self-perceptions of wealth, however this perception effect is not quantified (2002: 15). A short article based on findings from the Wealth and Responsibility Study 2000 finds a positive relationship between financial security and giving, leading the authors to conclude,

“it's not just the objective size of people's pocketbooks that matters but also their subjective sense of financial security" (Schervisch, Havens, and Whitaker 2005: 8) A study whose main focus was to create 'portraits of donors' generated interesting insights into money perceptions and financial insecurity in rich US households, finding that only $21 \%$ 
of households with a net-worth of $\$ 50 \mathrm{~m}$ or more reported feeling 'extremely financially secure' and $10.5 \%$ of these same households felt 'somewhat insecure' (Rooney and Frederick 2007:11). This objectively puzzling attitude to money is also described by Brooks who finds Americans in the upper income class describe themselves as "not being able to afford to give" because they have mortgages, car loans, and kids in college (Brooks 2006: 8). A disparity between apparent wealth and subjective assessments of wealth have also been noted in the UK, in a study of 76 people holding a net-worth of at least $£ 1$ million, $75 \%$ said they would increase their giving if they had more money and $25 \%$ described themselves as having 'low' financial security (Lloyd 2004: 104-5, 176-7).

Four further studies that touch on money perceptions include a bivariate analysis which found that people who perceive their financial situation as more positive are more generous donors (Havens, O'Herlihy, and Schervish 2007); a study which found that those who consider themselves 'financially better off than most other people' report higher donations to relief appeals (Bennett and Kottasz 2000); a study of graduate school alumni donations which found that alumni giving was higher among those who had more confidence in the economy (Okunade 1996); and a study that found an association between the individual's perception of a better financial position and the greater likelihood of sponsorship, attending charitable events, and donation in shops (Schlegelmilch, Love, and Diamantopoulos 1997).

\section{The neglect of money perceptions in philanthropic studies}

In comparison to the endless stream of papers that discuss and quantify other explanatory factors, such as tax breaks, religious beliefs and socialization, the potential explanatory power of money perceptions has been unwisely overlooked. For example, Woolf's summary of the economics of philanthropy (1999) suggests that three factors affect the amount that people give: their income or disposable resources, the cost of giving and the extent of demand by charities; this tripartite approach signally fails to include the supply-side of perceived wealth or ability to give. Yet sociologists and cultural anthropologists have long established that people can have very distinct perceptions of money and attitudes towards the distribution of personal wealth (monetary or otherwise). Consider for example the extensive literature on 'the gift' in anthropological research (Douglas 2002; Malinowski [1922] 1960; Mauss [1924] 2002) which emphasises the use of wealth and gifting as a means of personal display, for status building and to construct and reinforce alliances. Notable sociological studies on the social meaning of money include Furnham and Argyle's (1998) and Zelizer's studies (1989; 1994), which challenge the assumption that money is an abstract, impersonal and fungible construct by demonstrating,

"the remarkably various ways in which people identify, classify, organize, use, 
segregate, manufacture, design, store and even decorate monies as they cope with their multiple social relations... not all dollars are equal or interchangeable. We routinely assign different meanings and separate uses to particular monies" (Zelizer 1994:1, 5).

If we accept that different money perceptions exist, that 'not all dollars are equal', then it seems likely that people will also have different perceptions and attitudes regarding the dollars they have available (or not) for spending on charitable donations. In order to examine the effect of the perceived costs of giving, it is important to pay attention to the relationship of money perceptions with factors that affect the actual costs of giving because money perceptions are likely to have some relation to actual financial resources, as measured by income, financial stability and wealth.

In the rest of this paper we will examine how the attitudes that people hold towards money relate to the actual financial resources they possess, and how a combination of these money attitudes and actual financial resources affect charitable giving. We begin with a discussion of three measurable attitudes towards money: feelings of financial security, retention and inadequacy. These attitudes are illustrated with data from UK qualitative studies and hypotheses are generated regarding the extent that money perceptions and attitudes are anticipated to affect the incidence and level of charitable giving. The accounts of the wealthy specifically illustrate how monetary perceptions affect charitable donations for people with abundant financial resources. The monetary perceptions of these people should, theoretically, be less influenced by actual financial restrictions, whereas money perceptions of lower to middle-high income households are more likely to be affected by availability of actual financial resources.

The hypotheses are then empirically tested with quantitative data from the Giving in the Netherlands panel survey 2007 (GINPS07 2007). GINPS07 is a survey of 1,866 respondents, representative of the Dutch population. Most of these respondents have lower to middle-high income households. It is likely that their money perceptions are more strongly affected by actual financial resources than is the case for the wealthy British individuals. Therefore, we not only examine how money perceptions relate to incidence and level of charitable giving, but also how money perceptions relate to actual financial resources. 


\section{Money perceptions: definitions, illustrations and hypotheses}

The Money Beliefs and Behaviour Scale (MMBS) measures six factors in people's attitudes towards money: Obsession, Power, Retention, Conservative/Security, Inadequacy, and Effort/Ability (Furnham 1984; Wilhelm, Varcoe, and Fridrich 1993).

Whilst we would have liked to investigate the relationship between charitable giving and all six 'money attitudes' included in the MMBS, we only have measurements for the retention, conservative/security and inadequacy factors ${ }^{3}$ and therefore we focus on the relationship between these three attitudes and charitable giving.

To illustrate the existence and impact of these perceptions on charitable giving, we illustrate these attitudes with quotes from rich UK donors and non-donors; in this context 'rich' is defined as receiving an annual salary of $£ 80,000$ (c. $\$ 138,000 / € 100,000$ ) or net worth of at least $£ 1$ million (c.\$1.7million/€1.3million). These quotes, which all appeared originally in reports analyzing various aspects of the UK philanthropy sector, are used to formulate hypotheses on the relation between money attitudes and actual financial resources, and on the effects of money attitudes on incidence and level of charitable giving.

\section{Money perception 1: Financial security}

People who feel financially secure are those that have confidence in the ability to maintain their standard of living indefinitely, regardless of the impact of external factors, such as a recession. They are fully informed of their financial situation and handle their money with great care, knowing almost to the penny how much money they have in their purse and savings accounts at all times. Furthermore, they always pay bills promptly, and are proud of their ability to save money. A lack of financial security creates barriers to giving because money is defined as 'necessary' rather than 'surplus', and therefore not available for distribution. The presence of financial security removes such practical barriers to giving, as Schervish et al note, "For people who feel such security, philanthropic decisions really are different" (Schervisch, Havens, and Whitaker 2005: 8).

The presence of financial security is well illustrated by a UK-Asian self-made entrepreneur who draws on his perception of the term to explain his decision to become philanthropic.

"Seeing this deprivation first-hand [during a business trip to India] put my own financial position into context. I realised that I was financially secure - and

\footnotetext{
${ }^{3}$ Due to space issues in the GINPS07 questionnaire, only three factors from the MBBS scale could be measured, rather than the preferred inclusion of all six factors.
} 
privileged... I won't let myself forget the people in that slum in Bombay" (ACF 2005:116).

The lack of a sense of financial insecurity is illustrated by a number of rich non-givers in the UK:

"There was a time when I almost did a deal that was going to make me so ridiculously rich that I really didn't think that I'd ever have to worry about anything but what I would do with the money. That was the only time that I ever thought of setting up foundations to fund charitable organisations" (Edwards 2002:36)

"Most of your money is actually accounted for, it's got to go here, there and everywhere and what do you actually get to spend at the end of the day? Well, not very much really." (Edwards 2002:34)

"By the time you've got a car or two and a yacht and maybe a second home in the south of France or something, you can see that the bills add up" (John, Davies \& Mitchell 2008:21)

We anticipate that people's perceived level of financial security affects their charitable giving and hypothesize that:

H1a: People feeling less financially secure have a lower incidence and level of giving.

The quotes from UK rich non-givers, above, demonstrate that people who are objectively well off can still feel financially insecure. Having adequate actual financial resources is thus no guarantor of feeling financially secure. When even those with abundant financial resources experience feelings of financial insecurity, we expect no relationship between absolute financial resources and the money perception of financial security.

\section{Money perception 2: Retention}

The factor of 'retention' refers to the degree to which people have a careful approach to wealth and a preference not to spend money on anything (Furnham and Argyle 1998). People with strong feelings of retention prefer to save money, are fearful of lacking money in the future, often feel guilty about spending money (even on necessities) and have difficulties in making decisions about spending money, regardless of the amount involved and their actual ability to afford it. 
A further set of quotes from UK rich non-donors helps to flesh out the concept of retention: "I can put money into something and it may just go down the tubes, then you're in deep trouble. I've had a life of ups and downs so l'm very conscious of the value of money" (Edwards 2002:34).

"[including charities in one's will is] terrifying because of not knowing how long one person will survive and because of the terrifying changes in financial parameters. The percentage depends on the order of events. If we both go in a car crash $70 \%$ will go to charities; if I go first it will be 5\%" (Lloyd 2004:218).

"Altruism is fine for the people who have so much money it means nothing. That's the only type of altruism I can relate to" (Edwards 2003:15).

A number of rich donors expressly reject attitudes around retention, believing it is better to spend money and enjoy the consequences.

"It is only when you give it away, or consume, that money transforms from figures on a piece of paper to something in the world" ${ }^{4}$ (Sigrid Rausing, rich UK donor).

"I don't want to die rich. Money does not mean anything to me. I don't know why people who are extraordinarily wealthy are not more generous"5 (Anita Roddick, rich UK donor).

We therefore formulate the following hypothesis:

$\mathrm{H} 2$ : People with stronger feelings of retention have a lower incidence and level of giving.

One might argue that the rich experience stronger feelings of retention than people with lower or average incomes because their wealth is a result, at least in part, of their attitudes towards retention. Saving money, being fearful of lacking money in the future, feeling guilty about spending money (even on necessities) and having difficulties in making decisions about spending money regardless of the amount involved and their actual ability to afford it, are all characteristics that can lead to acquiring large amounts of absolute financial resources. However, as the quotes from Sigrid Rausing and Anita Roddick show, there are also examples of affluent individuals who experience no feelings of retention. Therefore,

\footnotetext{
${ }^{4}$ Quoted in the Guardian newspaper 9/6/04

${ }^{5}$ Quoted in the Sunday Times Rich List 2006
} 
based on the quotes from rich donors, we argue that there is no direct relationship between feelings of retention and absolute financial resources.

\section{Money perception 3: Inadequacy}

People who feel financially inadequate are those who worry about their financial situation most of the time, state that most of their friends have more money then they do, and believe that other people over-estimate their actual financial resources. Whilst we might predict inadequacy to be stronger amongst people at the lower end of the income scale, the final set of quotes show that even people with plentiful financial resources can feel inadequate when it comes to handling money.

"I don't consider myself that well off... We've got a house worth $£ 850,000$ that we bought for $£ 350,000$. We've got our eye on a house worth $£ 1.4$ million. When I look at the other dads at school I'm probably in the middle" (Edwards 2002:33)

"Wealthy? It's $£ 50$ million and upwards as far as I'm concerned. $£ 50$ million is the point at which you don't have to panic anymore" (Edwards 2002:35)

"I think l'd need to have something like £4 million in the bank to feel wealthy" (Edwards 2002:35)

This quote from a rich UK self-made man indicates awareness that his feelings around adequacy affect his willingness to make charitable donations:

"I hope to have enough money to have a significant change in lifestyle so I will be more able to give more time to the charitable sector through giving time and money. I have seen that happen - for example with a contemporary who gets $£ 20 m$ a year but now there are no bonuses" (Lloyd 2004:153)

Given the range of attitudes held by people who are similarly wealthy, we do not expect the effect of feelings of inadequacy to be mediated by actual financial resources. The final hypothesis offered is therefore:

H3: People who have stronger feelings of inadequacy when it comes to handling money have a lower incidence and level of giving. 


\section{The Giving in the Netherlands Panel Study}

We will now use quantitative data from the Giving in the Netherlands Panel Study 2007 (GINPS07 2007; N=1,866) to empirically test the hypotheses that were created with the help of the qualitative data from the UK.

GINPS is a bi-annual longitudinal study on charitable giving and volunteering in the Netherlands, which started in 2001. In May 2008, 1,866 persons were questioned about their household's donating behaviour during 2007, using Computer Assisted Self-Administered Interview procedures (CASI). The median annual after-tax income of the Dutch respondents is $€ 24,600$, and the highest income in the $9^{\text {th }}$ decile is $€ 42,000$. In comparison, in 2006 the median annual after-tax household income of the Dutch population is $€ 26,200$, and the highest income in the $9^{\text {th }}$ decile is $€ 52,500$ (Statistics Netherlands 2008). This indicates that respondents in GINPS07 are representative for Dutch lower to middle-high income households.

The two dependent variables in our research are the dichotomous variable of incidence of giving (whether or not a household made a donation to charitable organizations in 2007), and the natural log of the total amount of money that a household donated to charitable organizations in 2007. GINPS07 measures donations made to eleven particular sub-sectors of charitable organizations ${ }^{7}$, and uses an adaption of the 'IU-Method-Area'-module (Rooney, Steinberg, and Schervish 2001$)^{8}$. Of the 1,866 respondents that completed the questionnaire, only 192 households $(10.3 \%)$ indicated that they did not make a donation in 2007.

\section{How accurately does GINPS07 capture the MBBS factors?}

In GINPS07, respondents' attitudes towards money are measured with eleven 5-point Likert scale items, chosen from a larger set of items that showed validity in measuring the three

\footnotetext{
${ }^{6}$ The annual after-tax household incomes for 2007 are not yet available from Statistics Netherlands.

${ }^{7}$ These eleven sub-sectors of charitable organizations are: Religion, Health, International Aid, Environment protection, Nature protection, Animal protection, Education/Research, Culture, Sports/Recreation, and Public/Social Benefits, and other causes.

${ }^{8}$ First, respondents were questioned regarding which method they used to make a donation, for example, a collection tin or via a direct debit. Secondly, respondents were asked whether or not their household has made a donation to each of the 11 sub-sectors. Thirdly, the respondent was asked to state the exact amount of money given to each sub-sector in 2007. Respondents failing to state the size of donation were asked to indicate the amount donated to that particular sub-sector from the following categories: 1) less than $€ 5$; 2) $€ 5$ to $€ 10$; 3$) € 11$ to $€ 15$; 4$) € 16$ to $€ 25$; 5) $€ 26$ to $€ 50 ; 6) € 51$ to $€ 100 ; 7) € 101$ to $€ 200$; 8) more than $€ 200$; 9) no idea how much I donated; 10) I don't want to say how much I donated. $4.2 \%$ of all respondents had no idea how much they donated to at least one charitable subsector; $1.9 \%$ of the respondents did not want to say how much their household donated, again for at least one charitable subsector. We replaced this small proportion of missing donations with a conservative estimate of two euros per subsector, in line with Wiepking (Wiepking 2008).
} 
MBBS factors of security, inadequacy and retention as discussed above and in Furnham (1984) or in Wilhelm, Varcoe and Fridrich (1993).

Principal Component Analysis was used to test whether the items measured the three MBBS factors as intended. The results (displayed in table 1) show that they do satisfactorily measure perceptions relating to inadequacy, security and retention, all with an eigenvalue over 1. Together these factors explain $56.0 \%$ of total variance. However, the factor analysis showed that the first item we included to measure retention ("I prefer to save money, because I am never sure when things will collapse and I need the cash") is measuring security rather than retention. Theoretically, the item can indeed be interpreted as measuring both retention and security. In Furnham (1984), this item is included in both the measurement of retention and security but we decided to include this item solely in the measurement of security. This is because both the results for the factor- and the reliability analyses indicate that the item "I prefer to save money, because I am never sure when things will collapse and I need the cash" measures security rather than retention. The reliability is highest for the inadequacy measure, Cronbach's alpha is .73. Both the security and the retention measures score similarly on a reliability analysis, respectively Cronbach's alpha $=.66$ and Cronbach's alpha $=.64$.

$$
<<\text { Insert table } 1 \text { about here>> }
$$

\section{Actual financial resources}

We use four different indicators to measure actual financial resources: total after-tax household income, the price of giving, receiving income from wealth, and home ownership.

(1) Annual after-tax household income was measured by asking respondents about their own and (if applicable) their partner's monthly after-tax income from eight different sources $^{9}$. Respondents choosing not to state their exact income were offered indicative categories, which were recoded to the mean value, resulting in no missing values on the income variables. Total monthly after-tax income was calculated by adding all sources of income, multiplying by twelve to create an annual estimate and combining respondent and partner income (where applicable) to create a total for each household. We use the natural log of annual after-tax household income in the analyses.

(2) The price of giving for each household was calculated by using the formula

$$
P=(1-M T R)
$$

\footnotetext{
${ }^{9}$ Sources of income that respondents are asked about include paid work, welfare payments, social security benefits (unemployment, disability, and 'other'), pension, student benefits, and alimony.
} 
in which $P$ is the price of giving and MTR is the household's marginal tax rate ${ }^{10}$. For a household with a marginal tax rate of .52 , the price of giving is .48 , meaning it costs 48 cents to make a donation worth 1 euro. In our dataset, the highest price of giving is .84 and the lowest price of giving is .48 .

(3) Respondents were asked, as a dichotomous variable, whether they and/or their partner receive income from wealth. We found that $8 \%$ of the households in our dataset receive income from wealth.

(4) Home ownership is a common indicator of actual financial security (Banks and Tanner 1999; Todd and Lawson 1999) and is especially appropriate when studying groups of people in which actual financial resources mean that home ownership is not ubiquitous, as is the case in this dataset, as respondents demonstrate a low trough middle-high household income (up to $€ 120,000$ annual after tax household income).

$<<$ Insert table 2 about here $>>$

\section{Relationships between money perceptions and actual financial resources}

Table 3 shows the correlations between the three money perception measurements and three indicators of actual financial resources (total after-tax household income, receiving income from wealth, and home ownership). We excluded price of giving from this calculation because, being based on charitable tax breaks, it is a direct result of household income.

\section{Security and actual financial resources}

The relationships between perceptions of financial security and measures of financial resources are mixed. We find no relationship between security and household income (as anticipated). However, we do find a positive relationship between security and receiving income from wealth, and an unexpected negative relationship between security and home ownership such that people feeling more financially secure are less likely to be home owners and vice versa.

\section{Retention and actual financial resources}

We found a negative relationship between feelings of retention and all three measures of actual financial resources (household income, income from wealth and home ownership).

\footnotetext{
${ }^{10}$ The complete formula for price of giving from economic literature is $P=(1-M T R) /(1-O R)$, in which MTR is the marginal tax rate and OR is the overhead ratio for the receiving charity (Bowman 2006; Tinkelman 2004; Weisbrod and Dominguez 1986). We use the simplified formula, as we have no information on overhead ratio.
} 
When people with lower to middle-high incomes have greater actual financial resources at their command, they are less likely to have a careful approach to wealth and to express a preference not to spend money (and vise versa).

\section{Inadequacy and actual financial resources}

We found significant negative relationships between inadequacy and all three measures of actual financial resources. People who worry constantly about their financial situation and fear their wealth is over-estimated by others have lower actual financial resources, and vise versa.

\section{The effects of money perceptions on the incidence of charitable giving}

The results of the correlations between money perceptions and actual financial resources indicate that the perceived and actual costs of donations will be more intertwined than anticipated. However, these correlations do not indicate any causality: negative financial perceptions can lead to more negative actual financial resources and hence to lower incidence and level of giving, but the causality could also be reversed. In that case, lower actual financial resources would lead to negative financial perceptions, which in turn affect giving.

We now analyze the effects of money perceptions and actual financial resources on the incidence of charitable giving in three models, all shown within table 4 . Model 1 explores only the direct effects of money perceptions, Model 2 explores only the direct effects of actual financial resources, and Model 3 explores both money perceptions and financial resources simultaneously.

$$
<<\text { Insert table } 4 \text { about here >> }
$$

Model 1 shows the effects of money perceptions on giving. We find that feelings of financial security do not affect charitable giving but that both the factors of retention and inadequacy do have an effect on incidence of giving. This model demonstrates that people who have a careful approach to wealth and feelings of inadequacy concerning money have a lower probability of making donations.

Model 2 shows the effects of actual financial resources on the incidence of giving. We find a strong positive effect of home ownership on the incidence of giving. The effects of income and price of giving are only just significant. A ten percent increase in after-tax household income leads to an eleven percent higher probability of making donations. A one percent 
increase in the tax price of giving leads to a nine percent lower probability of making donations.

Model 3 shows the effects of both money perceptions and actual financial resources on giving. We find that the effect of perceptions of financial security is larger and significant once we control for home ownership, which we consider a measure of actual financial security. This indicates that perception of financial security is suppressed by actual financial security. Furthermore, we find that the effects of both feelings of retention and inadequacy on incidence of giving decrease somewhat (but still have a significant negative effect), once actual financial resources are taken into account. Some small part of the effect of attitudes towards retention and inadequacy on giving can be explained by people's actual financial resources. Crucially, the effects of income and price of giving on incidence of giving are found to be completely mediated; once we control for money perceptions, a higher income or lower price of giving no longer effect incidence of giving. The significant effect of home ownership on incidence of giving decreased slightly between Model 2 and Model 3 indicating that a small part of this effect is mediated, and is mediated by money perceptions.

\section{The effects of money perceptions on the scale of charitable giving}

Table 5 shows the results of Ordinary Least Squares regression analyses of the natural log of total amount donated to charitable organizations.

As in the preceding discussion, we analyze the effects of money perceptions and actual financial resources on the size of charitable gifts in three models, all shown within table 5 . Model 1 explores only the direct effects of money perceptions, Model 2 explores only the direct effects of actual financial resources, and Model 3 explores both money perceptions and financial resources simultaneously. As $89.7 \%$ of the respondents did make a donation in 2007, problems with sample selection and truncation are negligible (Bradley, Holden, and McClelland 2005; Wiepking 2008).

Model 1 in table 5 shows the effect of money perceptions on the size of gifts. We find significant negative effects for all three indicators of money perceptions. The strongest effect derives from feelings of inadequacy; people who more worry about their financial situation are found to donate lower amounts to charitable organizations. We also find a negative effect of retention; having a stronger preference not to spend money leads to donating lower amounts. Rather unexpectedly we find that people who feel more financially secure donate lower amounts to charitable organizations. We will return to this puzzling result in the discussion of Model 3. 
Model 2 in table 5 shows the results of the effects of actual financial resources on level of charitable giving. These results are very much in line with previous studies (Bekkers and Wiepking 2007; James III and Sharpe 2007) as we find a positive effect of home ownership, annual after-tax income, and receiving income from wealth, and a negative effect of price of giving on level of charitable donations. ${ }^{11}$

Model 3 in table 5 shows the effect of both money perceptions and actual financial resources on level of charitable giving. Combining these factors partly solves the puzzle thrown up in model 1 , whereby the financially secure appeared to give less than the insecure. Additional analyses show that the impact of feelings regarding financial security on level of giving is completely mediated by home ownership (which can be considered actual financial security). The question that remains is why there is a negative relationship between feeling financially secure and home ownership.

As in the complete model predicting incidence of giving (model 3 in table 4), model 3 in table 5 shows that the effects of both feelings of retention and inadequacy on level of giving are smaller (but still have a significant negative effect), once actual financial resources are taken into account. Small parts of the direct effect of retention and inadequacy on level of giving are thus mediated and can be explained by actual financial resources. When we consider the effects of actual financial resources on level of charitable giving in model 3 in table 5 , we see that the effect of price of giving is mediated by perceptions. Additional analyses reveal that this mediation takes place through feelings of retention and inadequacy. The effect of home ownership, after-tax household income, and income from wealth decrease somewhat between model 2 and model 3 in table 5, indicating that these effects are to some extent mediated by money perceptions. ${ }^{12}$

\section{Conclusion and discussion}

In this paper we demonstrated that differences between people in their perception and attitudes towards money can explain why some people choose, and others decline, to give money to charitable organizations, and why some people make larger donations than others, even when we hold constant for their actual financial resources. We formulated hypotheses

\footnotetext{
${ }^{11}$ We find an income elasticity of .15. Compared to results in American research, this is rather low (see for example Auten, Sieg, and Clotfelter 2002). However, in the Netherlands an income elasticity below .30 is common (Bekkers 2004; Wiepking and Maas forthcoming)

${ }_{12}$ Because price of giving is based on gross household income, we checked the Variance Inflation Factor (VIF) for Model 2 and Model 3 in table 4. The VIF is never larger than 1.6, indicating no serious problems with collinearity. Excluding the price of giving from analysis also does not change the results.
} 
on the effects of three money perceptions on incidence and level of charitable giving: feeling financially insecure, feelings of retention and feelings of inadequacy in handling money. Our results show that, regardless of actual financial resources, the decision to give is negatively affected by feelings of insecurity, retention and inadequacy. The amount people donate is also negatively affected by feelings of retention and inadequacy. The effects of money perceptions are mediated by actual financial resources. The effect of feelings of insecurity on incidence of giving is suppressed by actual financial security.

We illustrated our hypotheses with quotes from rich donors and non-donors in the UK. These quotes showed that even people with significant financial resources can demonstrate feelings of insecurity, retention and inadequacy. Therefore, we formulated most of our hypotheses based on the idea that money perceptions are not related to actual financial resources. However, when we tested our hypotheses with the Dutch data, we did find some relationships between money perceptions and actual financial resources.

This discrepancy could be due to a number of factors such as different composition of the qualitative and quantitative samples or cultural differences between the UK and the Netherlands. First and foremost, we expect this discrepancy to be due to the difference in level of actual financial resources of the respondents in both samples. We showed that for people in lower to middle-high income households (the Dutch sample) there is a relationship between money perceptions and actual financial resources. For affluent people (the UK sample), the relationship between money perceptions and level of actual financial resources is less clear. Additional data would be necessary to provide more insight into this relationship for people in high income households.

The Dutch data shows that people with stronger feelings of retention and inadequacy (people who have a careful approach to wealth, prefer not to spend money and worry about their finances) have a lower probability of making donations, and when they do donate they give lower amounts. These factors should be considered as important dispositional characteristics for predicting donations, just as altruistic values and empathic concern are widely understood to increase incidence and level of giving, so feelings of retention and inadequacy when it comes to handling money decreases it, regardless of people's actual financial resources.

Our other results show that the effect of the perception of financial security on incidence of giving is suppressed by actual financial security in the form of home ownership, and that the negative effect of perceived financial security on amounts donated is mediated by actual financial security. These results are caused by the unexpected negative relationship between feelings of financial security and actual financial security. One post-hoc explanation is that 
this might be the result of the measurements used for perceptual and actual financial security. The MBBS scale measures financial security with statements relating to being proud of the ability to save and paying bills promptly. Recalling that Furnham (1984) labelled this factor both 'security' and 'conservatives', we could infer that people who score highly on this factor are predominantly financially conservative. A mortgage is a major debt, which could be viewed as too onerous for financial conservatives to accept. This interpretation could explain the negative relation between our measurements of perceived and actual financial security. Ideally, the measurement of financial security would have also directly asked respondents: 'How financially secure do you feel?'. We believe this could address an unresolved issue raised in this paper concerning the effect of financial security on giving. In addition, it would also be useful to gain some insight into people's perception of, and confidence in, the economy in general (especially in these turbulent times of global economic crisis) in order to investigate how this relates to measures of money perceptions, actual financial resources and charitable giving. Future research could take these suggestions into account.

However interesting the findings of the present study, there are some methodological shortcomings that deserve attention. A recent study by Baker and Hagedorn (2008) shows for example that Yamauchi and Templer's 'money attitude scale' (MAS) (Yamouchi and Templer 1982) is less invariant and more reliable than Furnham's MBBS scale (Furnham 1984). In retrospect, it would have been better to have measured money perceptions in GINPS07 with items from the MAS scale rather than using the items for the three factors of security, inadequacy, and retention of the MBBS scale. However, in our case, the items included in GINPS07 to measure the MBBS factors turned out to measure the exact three factors of security, inadequacy, and retention as intended. These three factors can also considered reliable enough to investigate their relation with actual financial resources and giving (we measured the lowest Cronbach's alpha for the retention factor, .64 for three items). It would be interesting to measure both the MAS scale and the MBBS scale in future research and study how measurements of money perceptions obtained using both scales relate to actual financial resources and charitable giving.

In conclusion, how does this paper help us to understand the relationship between money perceptions and charitable giving? The implication of much of the data, especially the quotes, is that the rich under-estimate their wealth and fail to appreciate the capacity they have to undertake philanthropic acts, especially when their capacity is compared to the non-rich who, despite their lack of surplus wealth, give away a higher proportion of their income. But the findings might be due to a lack of empathy, rather than financial literacy, on the part of the 
rich. As Rousseau suggested nearly three centuries ago, the lives of the rich are so far removed from the lives of the poor that they lack any common fount of shared experience, "Why are kings without pity for their subjects? It is because they count on never being human beings. Why are the rich so harsh to the poor? It is because they do not have fear of becoming poor." (Rousseau cited in Nussbaum 2001:263,259)

If accusations of lack of empathy seems harsh, a more sympathetic approach suggests that money anxieties are experienced across the spectrum of wealth. Dr Terri Apter, a social psychologist at Newham College Cambridge who has studied motivation, says it is not uncommon even for rich donors to feel anxious each time they give.

'Typically there's the man who has a sinking feeling in his stomach every time he makes a large donation... It's the split between the reality of being rich now - but still having that self-image or those impulses that a not-rich person has. [They think], "Maybe tomorrow, given the markets and the exchange rates and property prices, this is going to look very stupid."'.

Given what has happened during the economic crisis in 2008, perhaps we can sympathise somewhat more convincingly with anxious billionaires, even whilst we use this research to shore up our efforts to encourage them to start, or expand, their philanthropic activities. 


\section{References}

Andreoni, James. 2004. "Economics of Philanthropy." Pp. 11369-11376 in Handbook of Giving, Reciprocity and Altruism, Handbooks in Economics, edited by L.-A. GerardVaret, S.-C. Kolm, and J. M. Ythier. North-Holland: Elsevier.

Auten, Gerald E., Holger Sieg, and Charles T. Clotfelter. 2002. "Charitable Giving, Income and Taxes: An Analysis of Panel Data." The American Economic Review 92:371-382.

Baker, Paul Morgan and Robert B. Hagedorn. 2008. "Attitudes to Money in a Random Sample of Adults: Factor Analysis of the MAS and MBBS Scales, and Correlations with Demographic Variables." The Journal of Socio-Economics 37:1803-1814.

Banks, James and Sarah Tanner. 1999. "Patterns in Household Giving: Evidence from UK Data." International Journal of Voluntary and Nonprofit Organizations 10:167-178.

Bekkers, René. 2004. "Giving and Volunteering in the Netherlands: Sociological and Psychological Perspectives." Dissertation, Department of Sociology, Utrecht University, Utrecht, the Netherlands.

Bekkers, René and Pamala Wiepking. 2007. "Generosity and Philanthropy: A Literature Review." SSRN Working paper series No. 1015507.

Bennett, Roger and Rita Kottasz. 2000. "Emergency fund-raising for disaster relief." Disaster Prevention and Management 9:352-359.

Bowman, Woods. 2006. "Should Donors Care About Overhead Costs? Do They Care?" Nonprofit and Voluntary Sector Quarterly June:288 - 310.

Bradley, Ralph, Steven Holden, and Robert McClelland. 2005. "A Robust Estimation of the Effects of Taxation on Charitable Contributions." Contemporary Economic Policy 23:545-554.

Breeze, Beth. 2006. "Dataset of UK Print Media Coverage in Philanthropy."

Brooks, Arthur C. 2006. Who Really Cares. The Surprising Truth about Compassionate Conservatism. New York: Basic Books.

Douglas, Mary. 2002. "Introduction: No Free Gifts." in The Gift, edited by M. Mauss. London and New York: Routledge.

Edwards, Laura. 2002. A Bit Rich. London: IPPR.

Furnham, Adrian. 1984. "Many Sides of the Coin: The Psychology of Money Usage." Personality and Individual Differences 5:501-509.

Furnham, Adrian and Micheal Argyle. 1998. The Psychology of Money. London, UK: Routledge.

GINPS07. 2007. Dataset: Giving in the Netherlands Panel Study 2007. Machine readable datafile. Amsterdam, the Netherlands: VU University Amsterdam. 
Havens, J.J., M.A. O'Herlihy, and P.G. Schervish. 2007. "Charitable Giving: How Much, by Whom, to What, and How?" in The Non-Profit Sector: A Research Handbook, edited by W. W. Powell and R. S. Steinberg. New Haven/London: Yale University Press. James III, Russell N. and Deanna L. Sharpe. 2007. "The Nature and Causes of the UShaped Charitable Giving Profile." Nonprofit and Voluntary Sector Quarterly 36:218238.

Lloyd, Theresa. 2004. Why Rich People Give. London: ACF.

Malinowski, Bronislaw K. [1922] 1960. Argonauts of the Western Pacific. New York, NY: Dutton.

Mauss, Marcel. [1924] 2002. The Gift. London, United Kingdom: Routledge.

Nussbaum, Martha. 2001. Women and Human Development: Capabilities Approach, vol. Bk IV. London: Cambridge University Press.

Okunade, A.A. 1996. "Graduate School Alumni Donations to Academic Funds: Micro-data Evidence." American Journal of Economics and Sociology 55:213-229.

Peloza, John and Piers Steel. 2005. "The Price Elasticities of Charitable Contributions: A Meta-Analysis." Journal of Public Policy \& Marketing 24:260-272.

Rooney, P. M. and H. K. Frederick. 2007. "Portraits of Donors: Bank of America Study of High Net-Worth Philanthropy." The Center on Philanthropy at Indiana University, Bloomington, IN.

Rooney, Patrick, Kathryn Steinberg, and Paul Schervish. 2001. "A Methodological Comparison of Giving Surveys: Indiana As a Test Case." Nonprofit and Voluntary Sector Quarterly 30:551-568.

Rosenberg, Claude. 1994. Wealthy and Wise: How You and America Can Get the Most Out of Your Giving. New York: Little, Brown and Company.

Schervisch, Paul, John Havens, and Albert Keith Whitaker. 2005. "Philanthropy's Indispensable Ally." Philanthropy XIX:8-9.

Schlegelmilch, B.B., A. Love, and A. Diamantopoulos. 1997. "Responses to Different Charity Appeals: The Impact of Donor Characteristics on the Amount of Donations." European Journal of Marketing 31:548-560.

Simmons, Walter. O. and Rosemarie Emanuele. 2004. "Does Government Spending Crowd Out Donations of Time and Money?" Public Finance Review 32:498-511.

Statistics Netherlands. 2008. "Household Income in Deciles in 2006." http://statline.cbs.nl/StatWeb/?LA=en [Accessed: October 13, 2008].

Steinberg, Richard. 1990. "Taxes and Giving: New Findings." Voluntas 1:61-79.

Tinkelman, Daniel. 2004. "Using Nonprofit Organization-level Financial Data to Infer Managers' Fund-raising Strategies." Journal of Public Economics 88:2181-2192. 
Todd, Sarah J. and Rob W. Lawson. 1999. "Towards a better understanding of the financial donor: An examination of donor behavior in terms of value structure and demographics." International Journal of Nonprofit and Voluntary Sector Marketing 4:235-244.

Vesterlund, Lise. 2006. "Why do People Give?" Pp. 568-590 in The Nonprofit Sector: A Research Handbook, edited by W. E. Powell and R. Steinberg. New Haven, CT: Yale University Press.

Weisbrod, Burton A. and Nestor D. Dominguez. 1986. "Demand for Collective Goods in Private Nonprofit Markets: Can Fundraising Expenditures Help Overcome Free-rider Behavior?" Journal of Public Economics 30:83-96.

Wiepking, Pamala. 2008. "For the Love of Mankind. A Sociological Study on Charitable Giving." Department of Philanthropic Studies, VU Amsterdam, Amsterdam.

Wiepking, Pamala and Ineke Maas. forthcoming. "Resources that Make You Generous: Effects of Social and Human Resources on Charitable Giving." Social Forces xx.

Wilhelm, Mari S, Karen Varcoe, and Angela Huebner Fridrich. 1993. "Financial Satisfaction and Assessment of Financial Progress: Importance of Money Attitudes." Financial Counseling and Planning 4:181-199.

Wolff, E. 1999. "The Economy and Philanthropy." Pp. 73-98 in Philanthropy and the Nonprofit Sector in a Changing America, edited by C. T. Clotfelter and T. Ehrlich. Indianapolis: Indiana University Press.

Wright, K. 2002. "Generosity vs. Altruism: Philanthropy and Charity in the United States and the United Kingdom." Voluntas 12:399-416.

Yamouchi, K.T. and D.L. Templer. 1982. "The Development of a Money Attitude Scale." Journal of Personality Assessment 46:522-528.

Zelizer, Viviana A. 1989. "The Social Meaning of Money: "Special Monies"." American Journal of Sociology 95:342-377.

—. 1994. The Social Meaning of Money. New York: BasicBooks. 
Table 2 Descriptive statistics of the variables used in this study

\begin{tabular}{|c|c|c|c|c|c|}
\hline & $\mathrm{N}$ & Min. & Max. & Mean & S.E. \\
\hline \multicolumn{6}{|l|}{ Dependent variables } \\
\hline Incidence of giving & 1866 & 0 & 1 & .897 & .304 \\
\hline Total amount donated (In) & 1866 & 0 & 1.52 & 3.885 & 2.013 \\
\hline \multicolumn{6}{|l|}{ Money perceptions } \\
\hline MBBS security & 1866 & 2 & 5 & 3.644 & .637 \\
\hline MBBS retention & 1866 & 1 & 5 & 2.557 & .734 \\
\hline MBBS inadequacy & 1866 & 1 & 5 & 2.836 & .775 \\
\hline \multicolumn{6}{|l|}{ Actual financial resources } \\
\hline Home ownership & 1866 & 0 & 1 & .559 & .497 \\
\hline Annual after-tax household income (In) & 1866 & 0 & 11.70 & 9.942 & 1.159 \\
\hline Price of giving & 1866 & .48 & .84 & .548 & .076 \\
\hline Income from wealth & 1866 & 0 & 1 & .080 & .271 \\
\hline
\end{tabular}


Table 3 Correlations between money perceptions and actual financial resources

\begin{tabular}{llll}
\hline & MBBS security & MBBS retention & MBBS inadequacy \\
\hline Home ownership & $-.069^{* *}$ & $-.106^{* *}$ & $-.157^{* *}$ \\
Annual after-tax household income $(\mathrm{In})$ & -.034 & $-.119^{* *}$ & $-.148^{\star *}$ \\
Income from wealth & $.050^{*}$ & $-.058^{*}$ & $-.189^{* *}$ \\
\hline
\end{tabular}

Notes: $\quad{ }^{(+)} p \leq .10 ;{ }^{*} p \leq .05 ;{ }^{* *} \mathrm{p} \leq .01$

Source: $\quad$ GINPS07 (2007) 
Table 4 Logistic regression of incidence of giving to charitable organizations in the Netherlands in 2007 (GINPS07, 2007; N=1,866)

\begin{tabular}{|c|c|c|c|c|c|c|c|c|c|c|c|c|}
\hline & \multicolumn{4}{|c|}{ Model 1} & \multicolumn{4}{|c|}{ Model 2} & \multicolumn{4}{|c|}{ Model 3} \\
\hline & $B$ & S.E. & $\operatorname{Exp}(B)$ & $p$ & $B$ & S.E. & $\operatorname{Exp}(B)$ & $p$ & $B$ & S.E. & $\operatorname{Exp}(B)$ & $p$ \\
\hline \multicolumn{13}{|l|}{ Money perceptions } \\
\hline MBBS security & .189 & .123 & 1.208 & & & & & & .256 & .124 & 1.292 & * \\
\hline MBBS retention & -.329 & .114 & .719 & $* *$ & & & & & -.294 & .115 & .745 & * \\
\hline MBBS inadequacy & -.430 & .106 & .650 & ** & & & & & -.314 & .107 & .731 & ** \\
\hline \multicolumn{13}{|l|}{ Actual financial resources } \\
\hline Home ownership & & & & & .732 & .168 & 2.080 & $* *$ & .684 & .170 & 1.981 & ** \\
\hline Annual after-tax household income (In) & & & & & .102 & .057 & 1.107 & $(+)$ & .089 & .057 & 1.093 & \\
\hline Price of giving & & & & & -2.077 & 1.107 & .125 & $(+)$ & -1.631 & 1.143 & .196 & \\
\hline Income from wealth & & & & & .273 & .341 & 1.314 & & .038 & .349 & 1.039 & \\
\hline Constant & 3.632 & .551 & 37.806 & $* *$ & 1.967 & & 7.146 & & 2.664 & 1.150 & 14.354 & * \\
\hline
\end{tabular}


Table 5 OLS Regression of the natural log of the total amount donated to charitable organizations in the Netherlands, 2007 (GINPS07, 2007; N=1,866)

\begin{tabular}{|c|c|c|c|c|c|c|c|c|c|c|c|c|}
\hline & \multicolumn{4}{|c|}{ Model 1} & \multicolumn{4}{|c|}{ Model 2} & \multicolumn{4}{|c|}{ Model 3} \\
\hline & $B$ & S.E. & Beta & $p$ & $B$ & S.E. & Beta & $p$ & $B$ & S.E. & Beta & $p$ \\
\hline \multicolumn{13}{|l|}{ Money perceptions } \\
\hline MBBS security & -.148 & .072 & -.047 & * & & & & & -.114 & .071 & -.036 & \\
\hline MBBS retention & -.256 & .068 & -.093 & $* *$ & & & & & -.223 & .067 & -.081 & ** \\
\hline MBBS inadequacy & -.402 & .064 & -.155 & ** & & & & & -.278 & .065 & -.107 & ** \\
\hline \multicolumn{13}{|l|}{ Actual financial resources } \\
\hline Home ownership & & & & & .526 & .098 & .130 & $* *$ & .466 & .097 & .115 & ** \\
\hline Annual after-tax household income (In) & & & & & .151 & .047 & .087 & ** & .139 & .046 & .080 & ** \\
\hline Price of giving & & & & & -1.578 & .744 & -.060 & * & -.862 & .742 & -.033 & \\
\hline Income from wealth & & & & & .747 & .168 & .101 & $* *$ & .605 & .169 & .082 & ** \\
\hline Constant & 6.221 & .330 & & ** & 2.891 & .773 & & $* *$ & 4.441 & .819 & & ** \\
\hline Adjusted R-square & .044 & & & & .057 & & & & .080 & & & \\
\hline
\end{tabular}

Notes: ${ }^{(+)} p \leq .10 ;{ }^{*} p \leq .05 ;{ }^{* *} p \leq .01$; 